it is possible to conclude that this new people was identical with that which formed the bulk of the population of the chief Hittite centres at Boghazkoi, Alishar and Alaga. This is the first occasion on which this culture has been found so far to the south-west. Its presence here may be expected to throw light on the difficult ethnological and historical problems of the second millennium B.C.

\section{Prehistoric Pottery in Kent}

THE results of further excavations in the Bean Valley, Kent, upon which Mr. J. P. T. Burchell made a report before the Society of Antiquaries of London on November 24, have failed to support the suggestion that the pottery discovered here in a previous investigation was of palæolithic age (see NATURE, 140,800 ; 1937.) The evidence upon which $\mathrm{Mr}$. Burchell relied in making such a suggestion was in part the absence of a mesolithic culture in the lower beds of the series in which the pottery occurred, in part the presence in the deposits of shells of the extinct Helicella striata, not previously recognized later than the Upper Palæolithic. Mr. Burchell's further examination of the site leads him to agree with the dissentient opinion previously expressed that this pottery is to be assigned to the early bronze age. It has been shown by this season's excavation that Helicella striata outlived the last glacial phase and survived into the mesolithic period. What was thought to be collateral evidence from Springhead in the Ebbsfleet valley in the form of striated implements showing the effect of glacial action has now proved to be later in date than two mesolithic floors in the valley, and consequently some other explanation of their condition must be sought. The excavations in the Ebbsfleet valley in the course of this further investigation have been pursued in exceptionally favourable conditions owing to pumping operations. It was found possible to excavate the bed of the stream to a depth of ten feet, and remains of cooking pots, decorated within and without, of a type not previously found in Britain, with flint flakes and fragments of worked wood of late mesolithic dating, were found in a grey silt below ten feet of peat.

\section{Electricity in Coal Mines}

Is a paper read by Mr. R. Nelson to the Institution of Electrical Engineers on December 1, a rotrospect is given of the use of electricity in coal mines during the last thirty years and also a forecast of what still remains to be done before the mines of Great Britain are fully electrified. In the year 1883, the first electric motor pump was used to pump water from a coal mine; it was only $1 \frac{1}{2}$ h.p., but there was then only very little mechanical power used for any purpose below ground. Twenty-five years ago the most disastrous explosion in the history of British mining, namely, that at Senghennydd Colliery, South Wales, had the effect of causing the miners to call for the removal of electricity from the pits. Happily, by the application of systematic stone dusting, a means was found of preventing the spread of an explosion of gas or coal-dust, and thereafter the miners' opposi- tion lessened, at any rate in degree, but it has not yet disappeared. During the last ten years, the coal industry has been greatly assisted by mechanized mining and mochanical methods of coal sorting. These, with normal development in other directions, have resulted in a total of more than two million horse power of motors installed in 1937, half of them being below ground. Accidont statistics are touched upon. It is recorded that, taken over ten years, 1927-1936 inclusive, electricity has been responsible for 224 out of 8,656 deaths, or $2 \frac{1}{2}$ per cent of the total loss of life in the pits. Electricity and compressed air are rival sources of power for the machine cutting of coal. In 1937 seventy per cent of the machine-cut coal was cut by electricity. It is satisfactory to learn that in some of the recently developed South Yorkshire and Nottinghamshire coalfields, their transmission mains are interconnected, a vory desirable example of co-operative working. The wider provision of cheap and unlimited current, by the 'grid' for example, would facilitate the use of electricity for all colliery purposes, and would improve the economics of the coal industry by materially assisting mechanical mining. The author concludes with an appeal to electrical engineers to capture the confidence of the miners.

\section{British Museum (Natural History): Acquisitions}

Mrs. Mary V. WALker has presented to the Department of Zoology a set of photographs which were taken by her husband, the late Dr. William D. Walker, depicting the early life history of kangaroos. The photographs show the kangaroo in all its stages from the newly born young one to the adult and mature individual. The first of the series shows the newly born kangaroo having just made its way into the pouch and it is seen adhering to one of the nipples. At this stage tho animal is very embryonic and bears but little resemblance to the massive creature into which it will grow, being scarcely more than an inch in length and looking more like a fragment of raw flesh than the young of any animal. A skin and seven sluulls of a rare species of otter (Paraony. microdon) have been presented by Mr. M. D. W. Jefferys. Mr. J. F. Perkins, assistant keeper in the Department of Entomology, spent six months from April until September 1938 in Sweden partly in the study of the important Thomson Collection of Ichneumonidæ (Hymenopterous insects the larvæ of which are parasitic on the larvæ of other insects), and partly in collecting insects, chiefly Ichneumonidæ, from the localities in Sweden where most of Thomson's specimens were obtained. More than 40,000 specimens of Hymenoptera were collected, of which 12,000 were Ichneumonidæ. A large quantity of the material obtained was identified and compared with the Thomson Collection before leaving Sweden, and the specimons so dealt with were found to represent 540 different species of which 260 were not previously to be found in the British Museum (Natural History). The collections obtained by Mr. Perkins constitute an important addition to the Entomological Department, and for the large number of specimens acquired and for the work done upon them in Sweden the Museum 
is indebted not only to Mr. Perkins but also to his wife, who accompanied and assisted him. Recent acquisitions in the Geological Department include nearly 300 invertebrate fossils from the Tertiary of the West Indies, collected and presented by Dr. C. T. Trechmann.

The Department of Botany has received the first consignment (2,800 specimens) of Dr. Carl Christensen's fern herbarium. Dr. Christensen is the chief authority on the taxonomy of ferns and is the author of "Index Filicum". It is estimated that the collection comprises more than 14,000 specimens with more than 800 types and 800 cotypes, and in addition fragments of 900 types and co-types; also more than 4,000 drawings, photographs and figures. The herbarium is without doubt the most important collection of ferns in private hands, and will add enormously to the value of the important fern section in the Department. The original drawings (426) illustrating the late E. D. Heatheote's "Flowers of the Engadine" have been presented to the Department by his daughter, Mrs. D. Lee. A further 600 specimens of flowering plants collected by Dr. H. Smith in Western China have been purchased. These are woll collected and preserved and contain several co-types. A collection of 984 lichens from northern Norway and from Baffin Land made by Dr. N. Polunin has been purchased. Although these are rather fragmentary owing to the difficulties of transport, the collections are important because they have been examined by experts and are the token specimens for several distribution records.

\section{Wild-Life of North-West England}

In a lecture to the Blackburn Naturalists' Field Club on November 26, Mr. Eric Hardy mentioned that oyster-catchers, curlew, woodcock, redshank, tawny owls and spotted woodpeckers, are all increasing their nesting range in Lancashire and Cheshire, but the terns are becoming fewer at the well-known Ainsdale sea-bird sanctuary. His subject of "On My Rounds: Notes From a Naturalist's Notebook" described his field studies in Knowsley Park, where great crested grebes, sandpipers, kingfishers and goldcrests are all common nesters and winter wildfowl visiting the great lake are more numerous and varied than at any other Lancashire water; he also showed a series of Dufay natural colour photographs taken at London Zoo this year and some scenes from Whipsnade Zoo, while the small herd of Chartley wild cattle there was compared with photographs of the original herd at Chartley Park, Staffordshire, now extinct, but of which Mr. Hardy has two valuable photographs taken by a Liverpool naturalist in 1891 when the historic herd totalled 52 and tuberculosis had not then broken out. At the Liverpool Cathedral Wild Birds' Sanctuary, said Mr. Hardy, there is a resident population of a few blackbirds, greenfinches, song thrushes and wrens, but in winter chaffinches, great tits, cole tits and golderests visit it and during migration willow-warblers are frequently heard, despite the sanctuary being in an old cemetery in the midst of city slums. From this position inside the city, valuable migration and other observations have been made, as a refuting of the old belief of great migrations of city sparrows to distant harvest fields, but owing to the position of a new masons' shed directly above the sanctuary, it has not been possible to attract many birds this year although the sanctuary is to be reconditioned and improved.

\section{Industrial Research in India}

THE report of the Industrial Research Bureau, Government of India, for the year 1937-38 (Delhi : Manager of Publications), covers the activities of the Industrial Research Council, the Industrial Research Bureau, which has been placed on a permanent basis as from March 1, 1938, and of the Research Branch of the Government Test House in the third year of its working. Special attention has been devoted to the improvement of glass products and, in addition to the work in this field described in a separate chapter of the report, including the improvement of glass furnaces and a survey of glass-making materials, the Council has authorized further work with an improved type of pot furnace. The Research Branch of the Government Test House has been responsible for a considerable amount of work on paints, natural weathering and accelerated weathering tests and also on the construction and performance of dry cells. Work has also been carried out on the use of vegetable oils as fuels and as lubricants for internal combustion engines, and promising results have been obtained with $\beta$-naphthol, diphenylamine, acetylphenylhydrazine and tin naphthenate as antioxidants in blends of castor oil with mineral oils. Information on the manufacture of casein and casein plastics in India is being collected, and a number of investigations on oils and soaps have been allocated. The report includes particulars of publications of the Bureau and of inquiries received.

\section{Research in Education in the United States}

As a step toward canalizing research activities in the field of secondary education, much of which might otherwise run to waste, the United States Office of Education has published a bulletin on "Needed Research in Secondary Education" (Washington, D.C. : Supt. of Documents. Pp. 70. Price $10 \mathrm{c.}$ ). The bulletin is largely based on the monographs of the National Survey of Secondary Education, a collection of important research studies (more than 4,400 pages in all) relating to organization of schools, the pupil, administrative and supervisory problems and personnel, the curriculum and "the extra-curriculum". Before proceeding to indicate specific problems needing investigation, the author discusses some general characteristics of contemporary methods of educational research, distinguishing, for the purpose of evaluating results, three levels of quality : the study of the results of practices (1) in any and all schools as found ; $(2)$ in schools selected for their outstanding merit, and (3) in experimental conditions set up especially for 